Jurnal Manajemen Bisnis

\title{
ANALISIS PERBANDINGAN KUALITAS PRODUK, STRATEGI PROMOSI DAN PERSEPSI KONSUMEN PADA PENGGUNA PONSEL OPPO \\ DAN XIAOMI (Studi Pada Mahasiswa Universitas \\ Muhammadiyah Tangerang)
}

\section{Tarto}

Universitas Muhammadiyah Tangerang

\begin{tabular}{|c|c|}
\hline INFO ARTKEL & A B S T R A C T \\
\hline \multirow[t]{3}{*}{$\begin{array}{l}\text { Keyword: } \\
\text { Product Quality, } \\
\text { Promotion Strategy, } \\
\text { Consumer Perceptions }\end{array}$} & $\begin{array}{l}\text { This study attempts to analyze comparison product quality, promotion strategy } \\
\text { and consumer perceptions between Oppo and Xiaomi smarphone. The } \\
\text { population of the research is Oppo and Xiaomi smarphone users. I00 Oppo } \\
\text { and Xiaomi smarphone users were surveyed as samples. The analysis technique } \\
\text { used is paired sample } t \text { test. The result showed that there are significant } \\
\text { differences between promotion strategy and consumer perceptions of Oppo and } \\
\text { Xiaomi, there is an insignificant difference between product quality of Oppo } \\
\text { and Xiaomi. }\end{array}$ \\
\hline & INTISARI \\
\hline & $\begin{array}{l}\text { Penelitian ini bertujuan untuk menganalisis perbandingan kualitas produk, } \\
\text { strategi promosi dan persepsi konsumen antara Oppo dan Xiaomi smarphone. } \\
\text { Populasi penelitian adalah pengguna oppo dan Xiaomi smarphone. I00 } \\
\text { pengguna oppo dan Xiaomi smarphone disurvei sebagai sampel. Teknik } \\
\text { analisis yang digunakan adalah paired sample } t \text { test. Hasil penelitian } \\
\text { menunjukkan bahwa ada perbedaan yang signifikan antara strategi promosi } \\
\text { Oppo dan Xiaomi, ada perbedaan yang signifikan antara persepsi konsumen } \\
\text { Oppo dan Xiaomi, dan terdapat perbedaan yang tidak signifikan antara } \\
\text { kualitas produk Oppo dan Xiaomi. }\end{array}$ \\
\hline
\end{tabular}

Corresponding author:

tartoasmara45@gmail.com 


\section{PENDAHULUAN}

\section{Latar Belakang Masalah}

Perkembangan teknologi telah menciptakan suatu bentuk media informasi dan telekomunikasi yang canggih. Salah satunya adalah dengan perkembangan industri telepon seluler (ponsel). Industri ponsel dewasa ini mengalami pertumbuhan yang cukup signifikan dan mengakibatkan tingkat kompetisi yang sangat tinggi pula.

Oppo dan Xiaomi yang merupakan dua perusahaan ponsel asal Tiongkok ini mempunyai penggemar yang cukup banyak di tanah air. Xiaomi terkenal dengan produk-produk bergaransi distributor yang berharga murah namun dengan spesifikasi tinggi. Sedangkan Oppo terkenal sebagai brand ponsel selfie dengan kamera depan yang superior.

Dari segi spesifikasi, masing-masing dari dua merek ini mempunyai karakter yang berbeda. Oppo lebih mengesampingkan spesifikasi tinggi namun mengklaim akan memberikan user experience atau pengalaman pengguna yang baik dengan berbagai produk yang ditawarkan. Sedangkan Xiaomi, lebih sering memberikan spesifikasi yang cukup tinggi dengan harga yang bisa dibilang terjangkau.

Oppo lebih dikenal dibanding Xiaomi bagi masyarakat awam karena memang Oppo sangat gencar melakukan promosi di berbagai media. Sedangkan Xiaomi, baru saja memenuhi aturan TKDN pada Desember 2016, sehingga membuat produk-produk Xiaomi lebih dikenal sebagai produk tidak resmi. Dan lagi, Xiaomi juga tidak melakukan kegiatan promosi di mediamedia mainstream, sehingga kebanyakan Xiaomi hanya dimengerti bagi orang yang paham tentang dunia gadget.

Dengan meningkatnya persaingan di industri ponsel membuat Oppo dan Xiaomi masing-masing menampilkan kualitas produk, strategi promosi, dan persepsi konsumen yang berbeda oleh karena itu melalui penelitian ini dapat dilihat perbandingan dari kualitas produk, strategi promosi, dan persepsi konsumen terhadap pengguna kedua merek ponsel tersebut khususnya pada mahasiswa Universitas Muhammadiyah Tangerang yang menjadi objek penelitian ini.

\section{Rumusan Masalah}

Rumusan masalah dalam penelitian ini adalah:

I. Apakah terdapat perbedaan yang signifikan antara kualitas produk dari ponsel Oppo dan Xiaomi.

2. Apakah terdapat perbedaan yang signifikan antara strategi promosi dari ponsel Oppo dan Xiaomi.

3. Apakah terdapat perbedaan yang signifikan antara persepsi konsumen dari ponsel Oppo dan Xiaomi.

\section{TINJAUAN PUSTAKA}

\section{Kualitas Produk}

Kualitas produk adalah kemampuan suatu produk untuk melaksanakan fungsinya, meliputi kehandalan, daya tahan, ketetapan, kemudahan operasi, dan perbaikan produk, serta atribut bernilailainnya (Kotler dan Amstrong, 2006). Sedangkan menurut American Society for Quality Control, kualitas produk adalah keseluruhan kelengkapan dan karakteristik dari produk tau ayanan yang memengaruhi kemampuannya untuk memuaskan kebutuhan baik yang dinyatakan maupun tersirat (Kotler dkk, 2004).

\section{Strategi Promosi}

Strategi merupakan konsep multi dimensi yang mencakup semua kegiatan kritikal suatu perusahaan yang memberikan kesatuan arah, tujuan dan memfasilitasi perubahan-perubahan yang diperlukan yang dipicu oleh lingkungan perusahaan (Chandler, 1962). Promosi adalah kegiatan yang ditujukan untuk mempengaruhi konsumen agar mereka dapat menjadi kenal akan produk yang ditawarkan oleh perusahaan kepada mereka dan kemudian mereka menjadi senang lalu membeli produk tersebut (Gitosudarmo, 2000)

\section{Persepsi Konsumen}

Menurut Schiffman dan Kanuk (2010), persepsi didefinisikan sebagai proses yang seorang individu memilih, mengorganisasi dan menginterpetasikan stimuli menjadi gambaran dunia yang berarti dan menyeluruh koheren Individu bertindak dan bereaksi berdasarkan persepsi mereka, tidak berdasarkan realitas yang objektif. Jadi, , persepsi konsumen jauh lebih penting dari pada pengetahuan mereka mengenai realitas yang objektif. Persepsi Konsumen adalah suatu proses yang membuat 
seseorang memilih, mengorganisasikan, dan menginterpretasikan rangsangan-rangsangan yang diterima menjadi suatu gambaran yang berarti dan lengkap tentang dunianya.

\section{Kerangka Pemikiran}

Kualitas menjadi penting bagi bisnis perusahaan, dengan menciptakan produk yang berkualitas perusahaan akan mendapatkan reputasi yang bagus di mata pelanggan. Kualitas menjadi kunci utama agar produk dikenal dan dipercaya masyarakat luas. Jika ingin meningkatkan loyalitas ke level yang lebih tinggi perusahaan perlu meningkatkan kualitas terlebih dahulu. Saat ini konsumen cenderung memilih sebuah produk karena kelebihannya, baik itu fitur yang lebih komplit atau pun pelayanan pelanggan yang lebih baik. Perusahaan harus bisa mewujudkannya dengan memberikan sesuatu yang selalu berbeda, yaitu apa yang tidak dimiliki oleh kompetitor dan menempatkan kualitas menjadi hal utama.

Promosi sangat penting dilakukan oleh perusahaan, karena saat melakukan promosi akan tercipta brand awareness yang membuat produk dikenal konsumen. Ini adalah alasan paling dasar dari sebuah strategi promosi yang perusahaan lakukan. Selanjutnya promosi berperan penting untuk membangun merek. Ketika konsumen sudah mengenal produk perusahaan (brand awareness tinggi) langkah kemudian adalah menciptakan kesan merek positif (brand image). Berikutya, promosi bermanfaat untuk meningkatkan loyalitas konsumen. Loyalitas konsumen menjadi sangat penting agar konsumen tidak beralih ke pesaing. Promosi juga berperan untuk menyampaikan suatu pesan ke target konsumen, terlebih lagi untuk produk yang relatif baru, konsumen perlu edukasi tentang kegunaan produk, cara pakai produk, dan berbagai hal yang berhubungan dengan produk. Hal ini menjadi alasan penting mengapa promosi wajib untuk dilakukan.

Persepsi merupakan interpretasi proses dimana konsumen memahami lingkungan mereka sendiri. Konsumen melihat apa yang mereka harapkan untuk melihat dan apa yang mereka harapkan untuk melihat tergantung pada kepercayaan umum dan stereotip. Dan karena setiap kelompok dan individu memiliki kepercayaan umum dan stereotip yang berbedabeda sehingga menimbulkan persepsi terhadap suatu lingkungan pemasaran juga menjadi beragam. Oleh karena itu, perusahaaan harus menyadari perbedaan tersebut agar dapat menyesuaikan stimuli pemasaran (yakni iklan, kemasan, harga dII) dengan persepsi mereka sehingga sesuai dengan segmen yang ditargetkan

Berdasarkan uraian di atas, kerangka konseptual penelitian tentang perbandingan kualitas produk, strategi promosi dan persepsi konsumen pada pengguna ponsel Oppo dan Xiaomi terlihat dalam gambar dibawah ini:

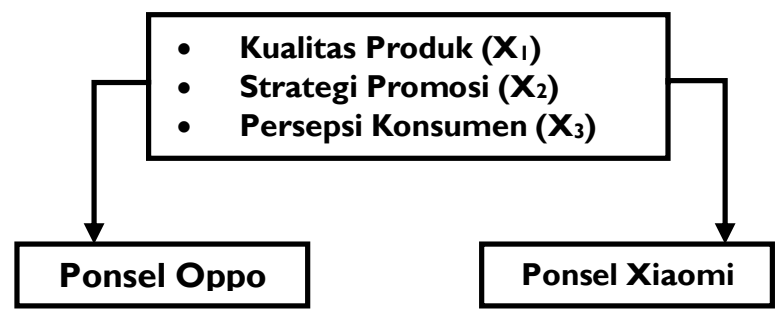

Gambar I. Kerangka Konseptual

\section{Hipotesis Penelitian}

HI: Terdapat perbedaan yang signifikan antara kualitas produk dari ponsel Oppo dan Xiaomi.

H2: Terdapat perbedaan yang signifikan antara strategi promosi dari ponsel Oppo dan Xiaomi.

H3: Terdapat perbedaan yang signifikan antara persepsi konsumen dari ponsel Oppo dan Xiaomi.

\section{METODE PENELITIAN}

\section{Jenis Penelitian}

Jenis penelitian yang digunakan dalam penelitian ini adalah penelitian komparatif yaitu suatu penelitian yang bersifat membandingkan yaitu membandingkan kualitas produk, strategi promosi dan persepsi konsumen dari suatu produk dengan produk yang lain. Penelitian ini bertujuan untuk mengetahui perbedaan kualitas produk, strategi promosi dan persepsi konsumen pada pengguna ponsel Oppo dan Xiaomi.

\section{Tempat dan Waktu Penelitian}

Lokasi penelitian ini dilakukan pada Universitas Muhammadiyah Tangerang. Waktu penelitian selama 5 minggu dan dilakukan dengan menyebarkan angket atau kuisioner.

\section{Populasi dan Sampel}

Populasi adalah wilayah generalisasi yang terdiri atas obyek/subyek yang mempunyai kualitas dan karakteristik tertentu yang 
diterapkan oleh peneliti untuk dipelajari dan kemudian ditarik kesimpulannya (Sugiyono, 20I2). Total populasi adalah jumlah mahasiswa Manajemen Universitas Muhammadiyah Tangerang tahun 2014-2018 sebanyak 14753. Sampel adalah bagian dari populasi dengan jumlah tertentu dan karakteristik (Sugiyono, 2012). Penarikan sampel dalam penelitian ini menggunakan teknik sampling purposif dengan menggunakan rumus Slovin. Jumlah sampel dalam penelitian ini adalah 100 orang.

\section{Jenis dan Sumber Data}

Data yang digunakan dalam penelitian ini terdiri dari data primer dan sekunder. Data primer yaitu data penelitian yang diperoleh secara langsung dari sumber asli. Data ini diperoleh dengan cara melakukan wawancara atau menyebarkan kuesioner kepada responden. Data sekunder adalah data yang diperoleh secara tidak langsung yaitu data yang diperoleh penulis dari dokumen-dokumen perusahaan dan buku-buku penunjang materi penelitian, jurnal, majalah, literatur-literatur yang terdapat di perpustakaan.

\section{Metode Analisis Data}

Metode analisis data yang digunakan dalam penelitian ini adalah analisis kuantitatif yaitu metode analisis dengan angka-angka yang dapat dihitung maupun diukur. Analisis kuantitatif dimaksudkan untuk memperkirakan besarnya pengaruh secara kuantitatif dari perubahan satu atau beberapa kejadian lainnya dengan menggunakan alat analisis statistik.

\section{Uji Validitas dan Uji Reliabilitas}

Valid berarti instrumen yang digunakan dapat mengukur apa yang hendak diukur (Ferdinand, 2006). Uji validitas biasanya digunakan dengan menghitung korelasi antara setiap skor butir instrumen dengan skor total (Sugiyono, 20II). Dasar pengambilan keputusan untuk menguji validitas indikatornya adalah:

I. Jika $r$ hitung positif dan $r$ hitung $>r$ tabel maka variabel tersebut valid.

2. Jika $r$ hitung tidak positif serta $r$ hitung $<r$ tabel maka variabel tersebut tidak valid.

Uji reliabilitas merupakan suatu pengukuran dan analisis terhadap data mengenai apakah layak atau tidaknya data tersebut digunakan dalam suatu penelitian (Sugiyono, 20I I). Suatu kuesioner dikatakan realiabel atau handal jika jawaban seseorang terhadap pertanyaan adalah konsisten atau stabil dari waktu ke waktu. Suatu variabel dikatakan reliabel jika memberikan nilai Cronbach Alpha lebih besar dari 0,6.

\section{Uji Normalitas}

Uji normalitas bertujuan unyuk menguji apakah dalaam model regresi, variabel penganggu atau residual memiliki distribusi normal. Seperti diketahui uji $T$ dan $F$ mengasumsikan bahwa nilai residual mengikuti distribusi normal. Dasar pengambilan keputusannya sebagai berikut:

I. Jika nilai probailitas $(\alpha)>0,05$; maka data tidak berdistribusi normal.

2. Jika nilai probabilitas $(\alpha) \leq 0,05$; maka data berdistribusi normal.

\section{Paired Sampel T Test}

Paied sample $T$ Test merupakan uji beda dua sampel berpasangan. Sampel berpasangan merupakan subjek yang sama namun mengalami perlakuan atau pengukuran yang berbeda. Kriteria pengambilan keputusan menggunakan nilai signifikan / P-Value:

I. Jika nilai signifikan / P-Value $>0,05$; maka perbedaan tidak signifikan

2. Jika nilai signifikan / $P$-Value $<0,05$; maka perbedaan signifikan

\section{HASIL PENELITIAN}

\section{Hasil Uji Validitas dan Reliabilitas}

Valid tidaknya suatu item instrumen dapat diketahui dengan membandingkkan nilai $r$ hitung dengan nilai $r$ tabel, Jika $r$ hitung lebih besar dari $r$ tabel dan bernilai positif, maka butir pertanyaan atau indikator dinyatakan valid.

Tabel I. Hasil Uji Validitas

\begin{tabular}{|c|c|c|c|c|c|c|}
\hline \multirow[b]{2}{*}{ Variabel } & \multirow[b]{2}{*}{ Indikator } & \multirow{2}{*}{$\begin{array}{c}\text { Nilai } r \text { tabel } \\
\text { df }=28 ; \\
\alpha=0,05\end{array}$} & \multicolumn{2}{|c|}{ Oppo } & \multicolumn{2}{|c|}{ Xiaomi } \\
\hline & & & $\begin{array}{c}\text { Nilai } \\
\mathrm{r} \text { hitung }\end{array}$ & Kriteria & $\begin{array}{c}\text { Nilai } \\
\mathrm{r} \text { hitung }\end{array}$ & Kriteria \\
\hline \multirow{4}{*}{$\begin{array}{l}\text { Kualitas } \\
\text { Produk }\end{array}$} & $\mathrm{X} 1.1$ & 0,361 & 0,544 & Valid & 0,376 & Valid \\
\hline & $\mathrm{X} 1.2$ & 0,361 & 0,434 & Valid & 0,539 & Valid \\
\hline & $\mathrm{X} 1.3$ & 0,361 & 0,397 & Valid & 0,607 & Valid \\
\hline & X1.4 & 0,361 & 0,368 & Valid & 0,563 & Valid \\
\hline \multirow{5}{*}{$\begin{array}{l}\text { Strategi } \\
\text { Promosi }\end{array}$} & $\mathrm{X} 2.1$ & 0,361 & 0,411 & Valid & 0,366 & Valid \\
\hline & $\mathrm{X} 2.2$ & 0,361 & 0,622 & Valid & 0,362 & Valid \\
\hline & $\mathrm{X} 2.3$ & 0,361 & 0,439 & Valid & 0,538 & Valid \\
\hline & $\mathrm{X} 2.4$ & 0,361 & 0,532 & Valid & 0,533 & Valid \\
\hline & $\mathrm{X} 2.5$ & 0,361 & 0,674 & Valid & 0,365 & Valid \\
\hline \multirow{3}{*}{$\begin{array}{l}\text { Persepsi } \\
\text { Konsumen }\end{array}$} & $\mathrm{X} 3.1$ & 0,361 & 0,364 & Valid & 0,375 & Valid \\
\hline & $\mathrm{X} 3.2$ & 0,361 & 0,382 & Valid & 0,536 & Valid \\
\hline & $\mathrm{X} 3.3$ & 0,361 & 0,488 & Valid & 0,557 & Valid \\
\hline
\end{tabular}

Sumber: Data primer diolah, 2017

Reliabilitas adalah tingkat kestabilan suatu alat pengukur dalam suatu gejala/kejadian. Suatu 
variabel dikatakan reliabel jika memberikan nilai Cronbach Alpha lebih besar dari 0,6.

Tabel 2. Hasil Uji Reliabilitas

\begin{tabular}{|l|c|c|c|c|c|}
\hline \multirow{2}{*}{ Variabel } & \multirow{2}{*}{ Cut off } & \multicolumn{2}{|c|}{ Oppo } & \multicolumn{2}{c|}{ Xiami } \\
\cline { 3 - 6 } & $\begin{array}{c}\text { Nilai } \\
\text { Cronbach } \\
\text { Alpa }\end{array}$ & Kesimpulan & $\begin{array}{c}\text { Nilai } \\
\text { Cronbach } \\
\text { Alpa }\end{array}$ & Kesimpulan \\
\hline Kualitas Produk & 0,6 & 0,645 & Reliabel & 0,724 & Reliabel \\
\hline Strategi Promosi & 0,6 & 0,761 & Reliabel & 0,663 & Reliabel \\
\hline Persepsi Konsumen & 0,6 & 0,647 & Reliabel & 0,635 & Reliabel \\
\hline
\end{tabular}

Sumber: Data primer diolah, 2017

Variabel penganggu atau residual memiliki distribusi normal dalam suatu model regresi dapat diketahui dengan melakukan uji Kolmogorov-Smirnov, jika Test Statistic lebih besar 0,05 dan Asymp. Sig. (2-tailed) kurang dari 0,05; maka data penelitian berdistribusi normal.

Tabel 3. Hasil Uji Normalitas dengan uji Kolmogorov-Smirnov

\begin{tabular}{|l|r|r|r|r|r|r|}
\hline & \multicolumn{3}{|c|}{ Oppo } & \multicolumn{3}{|c|}{ Xiaomi } \\
\cline { 2 - 7 } & Kualitas & Strategi & Persepsi & Kualitas & Strategi & \multicolumn{1}{c|}{ Persepsi } \\
& Produk & Promosi & Konsumen & Produk & Promosi & Konsumen \\
\hline Test Statistic & 0,164 & 0,184 & 0,150 & 0,157 & 0,110 & 0,184 \\
\hline Asymp. Sig. (2-tailed) & 0,000 & 0,000 & 0,000 & 0,000 & 0,005 & 0,000 \\
\hline
\end{tabular}

Sumber: Data primer diolah, 2017

Hasil uji Kolmogorov-Smirnov yang ditunjukkan pada tabel di atas menunjukkan Test Statistic lebih besar dari 0,05 dan Asymp. Sig. (2tailed) kurang dari 0,05. Dengan demikian, data pada penelitian ini berdistribusi normal.

\section{Hasil Analisis Uji Beda Kualitas Produk}

Tabel 4. Paired Samples Statistics

\begin{tabular}{|l|l|l|l|r|r|}
\hline \multicolumn{2}{|c|}{} & Mean & $N$ & $\begin{array}{c}\text { Std. } \\
\text { Deviation }\end{array}$ & $\begin{array}{c}\text { Std. } \\
\text { Error Mean }\end{array}$ \\
\hline \multirow{2}{*}{ Pair 1 } & Kualitas Produk Oppo & 16.1300 & 100 & 2.11610 & .21161 \\
\cline { 2 - 7 } & Kualitas Produk Xiaomi & 15.9400 & 100 & 2.37759 & .23776 \\
\hline
\end{tabular}

Sumber: Data primer diolah, 2017

Pada tabel di atas menunjukan bahwa untuk nilai rata-rata kualitas produk Oppo sebesar 16, I30 dengan standar deviasi sebesar 2, I I 6 dan nilai rata-rata kualitas produk Xiaomi sebesar I5,940 dengan standar deviasi sebesar 2,377.

Tabel 5. Paired Samples Test

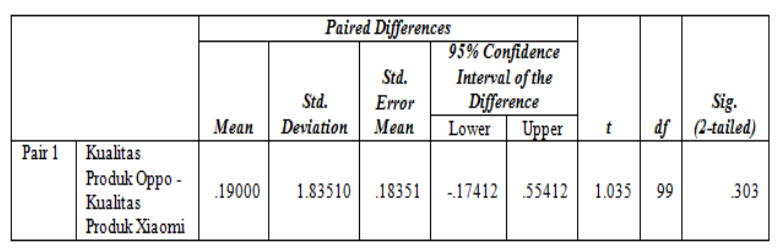

Sumber: Data primer diolah, 2017
Pada tabel di atas menunjukan bahwa nilai signifikan lebih dari 0,05 yaitu 0,303 artinya terdapat perbedaan yang tidak signifikan. Sehingga dapat disimpulkan bahwa Oppo dan Xiaomi memiliki Kualitas Produk yang tidak jauh berbeda.

\section{Hasil Analisis Uji Beda Strategi Promosi}

Tabel 6. Paired Samples Statistics

\begin{tabular}{|l|l|c|c|r|r|}
\hline \multicolumn{2}{|c|}{} & \multicolumn{1}{|c|}{ Mean } & N & $\begin{array}{c}\text { Std. } \\
\text { Deviation }\end{array}$ & \multicolumn{1}{c|}{$\begin{array}{c}\text { Std. } \\
\text { Error Mean }\end{array}$} \\
\hline Pair 1 & Strategi Promosi Oppo & 16.6400 & 100 & 2.01770 & .20177 \\
\cline { 2 - 7 } & Strategi Promosi Xiaomi & 16.1000 & 100 & 2.28522 & .22852 \\
\hline
\end{tabular}

Sumber: Data primer diolah, 2017

Pada tabel di atas menunjukan bahwa untuk nilai rata-rata strategi promosi Oppo sebesar 16,640 dengan standar deviasi sebesar 2,018 dan nilai rata-rata strategi promosi Xiaomi sebesar 65, 100 dengan standar deviasi sebesar 2,285.

Tabel 7. Paired Samples Test

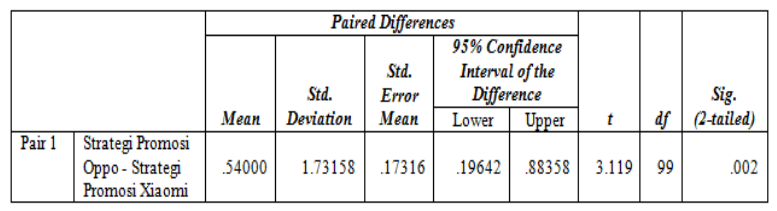

Sumber: Data primer diolah, 2017

Pada tabel di atas menunjukan bahwa nilai signifikan kurang dari 0,05 yaitu 0,002 artinya terdapat perbedaan signifikan. Sehingga dapat disimpulkan bahwa Oppo dan Xiaomi memiliki strategi promosi yang berbeda.

\section{Hasil Analisis Uji Beda Persepsi Konsumen}

Tabel 8. Paired Samples Statistics

\begin{tabular}{|l|l|c|c|r|r|}
\hline \multicolumn{2}{|c|}{} & Mean & N & $\begin{array}{c}\text { Std. } \\
\text { Deviation }\end{array}$ & $\begin{array}{c}\text { Std. } \\
\text { Error Mean }\end{array}$ \\
\hline Pair 1 & Persepsi Konsumen Oppo & 11.7100 & 100 & 1.51954 & .15195 \\
\cline { 2 - 6 } & Persepsi Konsumen Xiaomi & 12.1000 & 100 & 1.66667 & .16667 \\
\hline
\end{tabular}

Sumber: Data primer diolah, 2017

Pada tabel di atas menunjukan bahwa untuk nilai rata-rata persepsi konsumen Oppo sebesar II,7 I0 dengan standar deviasi sebesar I,5I9 dan nilai rata-rata persepsi konsumen Xiaomi sebesar 12,100 dengan standar deviasi sebesar I,667. 
Tabel 9. Paired Samples Test

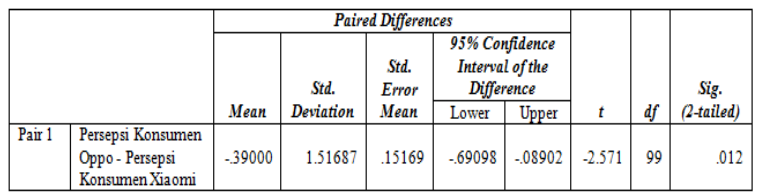

Sumber: Data primer diolah, 2017

Pada tabel di atas menunjukan bahwa nilai signifikan kurang dari 0,05 yaitu 0,012 artinya terdapat perbedaan signifikan. Sehingga dapat disimpulkan bahwa Oppo dan Xiaomi memiliki persepsi konsumen yang berbeda.

\section{PEMBAHASAN}

Berdasarkan pada hasil analisis uji beda menunjukkan bahwa terdapat perbedaan yang signifikan antara strategi promosi dari Oppo dan Xiaomi, sama halnya pada persepsi konsumen dimana terdapat perbedaan yang signifikan antara persepsi konsumen dari Oppo dan Xiaomi, sedangkan pada kualitas produk menunjukkan bahwa terdapat perbedaan yang tidak signifikan antara kualitas produk dari Oppo dan Xiaomi. Berikut ini uraian selengkapnya dari hasil penelitian mengenai perbedaan kualitas produk, strategi promosi dan persepsi konsumen pada pengguna Oppo dan Xiaomi.

\section{Kualitas Produk Oppo dan Xiaomi}

Dari hasil penelitian uji beda yang sudah dilakukan menunjukkan bahwa terdapat perbedaaan yang tidak signifikan antara kualitas produk dari Oppo dan Xiaomi dimana hasil yang didapat sebesar 0,303 yang artinya nilai signifikansi lebih dari 0,05 (5\%) dari hasil tersebut dapat disimpulkan bahwa Oppo dan Xiaomi memiliki kualitas yang tidak jauh berbeda Meskipun Oppo memiliki nilai rata-rata tertinggi tapi keduanya tetap memiliki kualitas yang setara, kualitas dalam artian bahwa keduanya memiliki desain yang bagus, memiliki fitur yang lengkap, kemampuan kamera yang baik dan prosesor yang handal.

\section{Strategi Promosi Oppo dan Xiaomi}

Dari hasil penelitian uji beda menunjukkan bahwa terdapat perbedaan yang signifikan pada strategi promosi dari Oppo dan Xiaomi, dimana hasil signifikansi yang didapat sebesar 0,002 atau kurang dari 0,05 (5\%) dengan nilai rata-rata tertinggi terdapat pada Oppo yaitu 16,640 sehingga dapat disimpulkan bahwa strategi promosi yang dilakukan Oppo untuk menarik perhatian pelanggan berbeda dengan Xiaomi, dari tampilan gambar iklan, intesitas penayangan iklan, bahasa yang digunakan dalam iklan informasi atau pesan yang disampaikan lewat iklan menarik, mudah diingat dan dimengerti oleh konsumen.

\section{Persepsi Konsumen Oppo dan Xiaomi}

Hasil penelitian uji beda menunjukkan bahwa terdapat perbedaan yang signifikan pada persepsi konsumen Oppo dan Xiaomi dimana hasil signifikansi yang didapat sebesar 0,012 atau kurang dari 0,05 (5\%) dengan nilai rata-rata tertinggi terdapat pada Xiaomi yaitul2, 100 sehingga dapat disimpulkan bahwa persepsi konsumen Xiaomi berbeda dengan persepsi konsumen Oppo. Xiaomi memiliki harga yang lebih terjangkau dan sesuai dengan produk yang dihasilkan, konsumen merasa puas terhadap fitur-fitur produk yang ditawarkan, dan memberikan pelayanan yang cepat dan sesuai harapan.

\section{PENUTUP}

\section{Kesimpulan}

Berdasarkan hasil penelitian yang telah dilakukan maka dapat ditarik kesimpulan sebagai berikut:

I. Terdapat perbedaan yang tidak signifikan antara Kualitas Produk ponsel Oppo dan Xiaomi.

2. Terdapat perbedaan yang signifikan antara Strategi Promosi ponsel Oppo dan Xiaomi.

3. Terdapat perbedaan yang signifikan antara Persepsi Konsumen ponsel Oppo dan Xiaomi.

\section{Saran}

I. Untuk produsen Oppo diharapkan agar selalu konsisten dalam memberikan fiturfitur dan desain yang bagus dan selalu melakukan perkembangan pada produknya.

2. Untuk produsen Xiaomi diharapkan dapat meningkatkan strategi promosi melalui iklan-iklan yang ditampilkan dari media elektronik agar lebih menarik lebih banyak mendapatkan konsumen.

3. Untuk penelitian yang akan datang disarankan untuk meneliti ponsel lain dengan variabel penelitian lainnya. 
DAFTAR PUSTAKA

Chandler, Alfred Jr., 1962, Strategy and Structure: Chapters in the History of the American Industrial Enterprise, MIT.

Ferdinand, Augusty. 2006, Metode Penelitian Manajemen, Edisi 2. Semarang: Badan Penerbit Universitas Diponegoro.

Gitosudarmo, Indriyo. 2000, Manajemen

Pemasaran. Yogyakarta: BPFE UGM.

Kotler, Philip dan Armstrong. 2006, PrinsipPrinsip Pemasaran, Edisi Ke-I2. Jakarta: Erlangga.

Kotler, Philip dkk. 2004, Manajemen Pemasaran dari Sudut Pandang Asia. Jakarta: Indeks.

Schiffman, Leon G. dan Leslie Lazar Kanuk. 2010, Consumer Behavior, Tenth Edition. Pearson Education.

Sugiyono. 20I I, Statistika Untuk Penelitian. Bandung: Alfabeta

Sugiyono. 2012. Metode Penelitian Bisnis, Cetakan Keenam Belas, Bandung: Alfabeta. 